\title{
INFORMĀCIJAS AVOTU AIZSARDZĪBA - ŽURNĀLISTA TIESĪBAS VAI PIENĀKUMS?
}

\section{PROTECTION OF JOURNALIST'S INFORMATION SOURCES - RIGHT OR DUTY?}

\author{
Linda Bīriṇa, Mg. iur. \\ Zvērināta advokāte, Latvijas Universitātes Juridiskās fakultātes doktorante
}

\begin{abstract}
Summary
International law provides strong protection to journalists enabling them to refuse to divulge their confidential sources of information. However, there may be situations when a journalist is willing to expose the name of a confidential informant who had tried to manipulate the journalist by passing on false information. The article strives to determine whether protection of sources from journalist's perspective is an absolute duty or it is a right that the journalist can choose to enforce depending on the particular situation. The author provides an insight into different approaches of ethical and legal requirements related to journalist's right and duty to protect sources and concludes that an absolute duty should be avoided.
\end{abstract}

Atslēgvārdi: vārda brīvība, žurnālistu avotu aizsardzība, žurnālistu ètika.

Keywords: freedom of expression, protection of journalist's source, journalist ethics.

\section{Ievads}

Nav šaubu par to, ka žurnālistu informācijas avotu aizsardzība veido pamatu žurnālistu darbam un brīvībai, tostarp mediju brīvībai. ${ }^{1}$ Preses pieeja konfidenciālai, bet sabiedrībai būtiskai informācijai ir iespējama tikai tajā gadījumā, ja žurnālisti var garantēt avotu konfidencialitāti un anonimitāti. ${ }^{2}$ Žurnālistu spēja aizsargāt savu avotu konfidencialitāti ir būtiska, lai nodrošinātu spēcīgus un neatkarīgus medijus un demokrātiskas sabiedrības labu funkcionēšanu. Informācijas avoti pal̦aujas uz to, ka žurnālisti ievēros konfidencialitāti un neatklās savu informācijas avotu identitāti neatkarīgi no ārējiem apstākḷiem.

Juridiskajā literatūrā un tiesu praksē biežāk tiek aplūkots jautājums, vai un kādos gadījumos tiesībsargājošās iestādes var pieprasīt žurnālistiem atklāt informācijas avotus. Kā izriet no Eiropas Cilvēktiesību tiesas (turpmāk - ECT) prakses, īpašos izṇēmuma gadỉjumos valsts varētu prasīt žurnālistiem atklāt viṇu informācijas avotus vai veikt darbības, kuru rezultātā var tikt atklāti žurnālistu

${ }^{1}$ Council of Europe. Recommendation No. R (2000) 7 of the Committee of Ministers to Member States on the right of journalists not to disclose their sources of information. Committee of Ministers. $701^{\text {st }}$ meeting of the Ministers' Deputies. 8 March 2000.

2 ECT 12.04.2012. spriedums lietā Martin and others v. France (iesnieguma Nr. 30002/08). 
informācijas avoti. ${ }^{3}$ Tomēr biežāk šie izṇēmuma gadījumi tiek tulkoti pārāk plaši vai arī nacionālie tiesību akti nemaz neparedz pietiekamu aizsardzību no nepamatotas iejaukšanās. Līdz ar to, ja žurnālisti vienmēr apzinīgi pildītu tiem izvirzìto prasību atklāt savus informācijas avotus, avotu aizsardzība varētu zaudēt savu jēgu. Tādēl praksē daudz žurnālistu ir izvēlējušies pat cietumsodu, bet nav izpildījuši tiesībsargājošo iestāžu prasību atklāt savus informācijas avotus. Šādā veidā žurnālisti demonstrē visai sabiedrībai, ka informācijas avotu aizsardzību uztver par savu absolūtu pienākumu neatkarīgi no tā, ka tādā veidā rīkojas pretēji likumam. No vienas puses, kad žurnālisti "augstāku” mērḳu vārdā nepilda tiesas lēmumu, tie apdraud preses brīvību, jo parāda necieņu likuma un tiesu varai. Vienlaikus likuma un tiesu varai ir jārespektē arī tiesiska nepieciešamība pēc brīvas preses, kas ietver nepieciešamību aizsargāt informācijas avotus. ${ }^{4}$

Taču šis jautājums būtu vērtējams ne tikai no tiesībsargājošo iestāžu rīcības tiesiskuma prizmas, bet arī no pašu žurnālistu perspektīvas. ASV Augstākā tiesa lietā Cohen v. Cowles Media Co ir secinājusi, ka žurnālistiem nav tiesību atklāt savus avotus, ja viṇi ir solījuši saglabāt avotu konfidencialitāti. ${ }^{5}$ Tāpat arī žurnālistu un mediju profesionālās organizācijas savos ètikas kodeksos pārsvarā nosaka avotu aizsardzību kā žurnālistu pienākumu, nevis tiesības. Taču jāṇem vērā, ka ne vienmēr informācijas avoti rīkojas godprātīgi, atklājot noteiktu informāciju žurnālistiem. Nevar izslēgt situācijas, kad žurnālists ir konstatējis, ka tā informācijas avots ir sniedzis nepatiesu informāciju vai maldinājis žurnālistu, lai realizētu kādas personīgas intereses ar žurnālista starpniecību. Šādu gadījumu praksē ir bijis salīdzinoši daudz. Piemēram, Apvienotajā Karalistē avoti medijiem nodeva falsificētus dokumentus par uzṇēmumu Interbrew, tādā veidā mēgeinot manipulēt ar uzñēmuma akciju vērtību. ${ }^{6}$

Atsevišķos gadījumos arī paši žurnālisti, secinot, ka tiek izmantoti nelikumīgiem mērķiem, ir publiski atklājuši informācijas avota identitāti, kaut arī bija apsolījuši ievērot konfidencialitāti. ${ }^{7}$ Tādējādi žurnālists var nonākt situācijā, kurā labprātīgi vēlas atklāt sava avota identitāti.

Šì raksta mērķis ir censties rast atbildi uz jautājumu, vai savu informācijas avotu aizsardzība ir žurnālistu absolūts pienākums vai arī tās ir tiesības, kuras žurnālists atkarībā no apstākḷiem var izmantot vai neizmantot. Šì raksta pirmajā daḷā tiks sniegts ieskats žurnālistu profesionālās darbības jeb ètikas un normatīvā regulējuma atšķirīgajā pieejā attiecībā uz to, vai avotu aizsardzība ir nosakāma kā žurnālista tiesības vai pienākums. Savukārt raksta otrajā daḷā tiks aplūkots Latvijas regulējums šajā jautājumā.

\footnotetext{
${ }^{3}$ Sk., piemēram, ECT 27.05.2014. lēmums lietā Stichting Ostade Blade v. the Netherlands, (iesnieguma Nr. 8406/06); ECT 08.12.2005. lēmums lietā Nordisk Film \& TV A/S v. Denmark (iesnieguma Nr. 40485/02).

${ }^{4}$ Stone, Geoffrey R. The Merits of the Proposed Journalist - Source Privilege. The Journal of the ACS Issue Briefs, 2007, Vol. 1, Hein Online database, p. 67.

5 "Privacy International" pētijums "Silencing Sources: An International Survey of Protections and Threats to Journalists' Sources”, 28. lpp. Pieejams: https://papers.ssrn.com/sol3/papers.cfm?abstract_id=1706688 [aplūkots 09.03.2021.].

${ }^{6}$ ECT 15.12.2009. spriedums lietā Financial Times Ltd. and Others v. The United Kingdom (iesnieguma Nr. 821/03).

7 Brady R. Protecting our sources of information. Why journalists need to resist legal attacks. European $\mathrm{Fe}-$ deration of Journalists, 2004, p. 23. Pieejams: https:/www.statewatch.org/media/documents/news/2005/ dec/ifj-sources-handbook.pdf [aplūkots 09.03.2021.].
} 
Daudzās valstīs žurnālistu profesionālās darbības un ētikas kodeksi paredz žurnālista pienākumu sargāt savus informācijas avotus. ${ }^{8}$ Arī Starptautiskā Žurnālistu federācija, kas ir pasaulē lielākā žurnālistu organizācija, pārstāvot aptuveni 600000 biedru 140 valstīs, ir noteikusi, ka žurnālistiem ir jāievēro profesionālais noslēpums attiecībā uz saviem informācijas avotiem. ${ }^{9}$ Starptautiskās Žurnālistu federācijas Vispārējā žurnālistu ètikas harta ${ }^{10}$, kas papildina Deklarāciju par žurnālistu uzvedības principiem, ${ }^{11}$ noteic, ka žurnālistiem ir jāievēro profesionālais noslēpums attiecībā uz informācijas avotiem, kas iegūti, paḷaujoties uz konfidencialitāti. Šì starptautiskā deklarācija tiek uzskatīta par žurnālistu profesionālās uzvedibas standartu. ${ }^{12}$

Eiropas Padomes dalībvalstis jau 1994. gadā pieņēma rezolūciju, kurā vienojās par kopīgiem principiem attiecībā uz žurnālistu pienākumiem un atbildību, kas būtu nosakāmi nacionālajos uzvedības jeb ètikas kodeksos. ${ }^{13}$ Rezolūcijas 3. princips noteic, ka žurnālistu avotu aizsardzības konfidencialitātes nodrošināšana ir viens no četriem līdzekḷiem, kas žurnālistikai l̦auj sniegt ieguldỉjumu patiesas demokrātijas uzturēšanā un attīstībā. Savukārt 7. princips paredz pienākumu ievērot profesionālo noslēpumu attiecībā uz informācijas avotiem.

Eiropas Žurnālistu federācija šajā jautājumā ir norādījusi uz to, ka dažādu valstu žurnālistu ētikas kodeksos pieeja ir atškirīga. Ir valstis, kurās žurnālistu ètikas kodeksi paredz pienākumu sargāt informācijas avotu, nenosakot nekādus izņēmumus šādam pienākumam, bet ir arī tādas, kur ir paredzēti izṇēmumi situācijās, kad informācijas avots ir izmantojis žurnālistu, lai izplatītu nepatiesu informāciju. Eiropas Žurnālistu federācija uzskata, ka šis jautājums nav viennozīmīgs un būtu izlemjams katrā konkrētā situācijā individuāli. Tādējādi katram žurnālistam vajadzētu atbildīgi pieņemt lēmumu, izvērtējot visus apstākḷ̂s un iespējamās sekas. Primāri būtu jāuzskata, ka žurnālistam ir pienākums sargāt sava informācijas avota identitāti, taču piel̦aujot arī izņēmumus no ši pienākuma. ${ }^{14}$

Piemēram, Norvēgijas laikraksts Bergens Avisen izlēma atklāt konfidenciāla informācijas avota vārdu, kurš centās manipulēt ar laikrakstu, sniedzot nepatiesu informāciju. Taču par šādu rīcību citi žurnālisti laikrakstu asi kritizēja. ${ }^{15}$ Attiecīgi pat šādās situācijās, kad informācijas avots ir bijis negodprātīgs, žurnālistu

8 "Privacy International" pētijums "Silencing Sources: An International Survey of Protections and Threats to Journalists' Sources”, 27. lpp. Pieejams: https://papers.ssrn.com/sol3/papers.cfm?abstract_id=1706688 [aplūkots 09.03.2021.].

9 The International Federation of Journalists (IFJ). Pieejams: https://www.ifj.org/who/about-ifj.html [aplūkots 09.03.2021.].

${ }_{10}$ Global Charter of Ethics for Journalists, 12.06.2019. Pieejams: https://www.ifj.org/who/rules-and-policy/ global-charter-of-ethics-for-journalists.html [aplūkots 09.03.2021.].

11 Declaration of Principles on the Conduct of Journalists, 05.05.2003. Pieejams: https://www.ifj.org/ media-centre/news/detail/category/europe/article/status-of-journalists-and-journalism-ethics-ifjprinciples.html [aplūkots 09.03.2021.].

12 Freedom of Expression and Public Order. Training manual. UNESCO, 2015, p. 48. Pieejams: https:// unesdoc.unesco.org/ark:/48223/pf0000231305 [aplūkots 09.03.2021.].

13 Resolution No. 2: Journalistic Freedoms and Human Rights, 4th European Ministerial Conference on Mass Media Policy - Prague, 7-8 December 1994.

14 Brady R. 2004, p. 22.

15 Ibid, p. 8. 
viedoklis par to, vai no profesionālās ètikas viedokḷa būtu attaisnojama avota identitātes atklāšana, atšksiras.

Vienlaikus žurnālistiem ir vienots uzskats, ka ši jautājuma izlemšana būtu jāatstāj pašu žurnālistu, nevis tiesas ziṇā. Eiropas Žurnālistu federācija uzskata, ka katram žurnālistam ir jābūt gatavam doties apcietinājumā, ja vien tas ir nepieciešams, lai aizsargātu savus informācijas avotus, jo avotu aizsardzība ir demokrātijas jautājums. $^{16}$

Un tiešām, žurnālisti gadiem ilgi šo profesionālo pienākumu ir stādījuši augstāk pat par tiesas un likuma varu, izvēloties drīzāk doties apcietinājumā nekā atklāt savus informācijas avotus. ${ }^{17}$ Šādas pieejas iemesls ir pārliecỉba, ka informācijas avotu aizsardzība ir viens no būtiskākajiem pamatiem preses brīvības nodrošināšanai demokrātiskā sabiedrībā.

Atskatoties vēsturē, viena no pirmajām dokumentētajām tiesvedībām Amerikā, kuras laikā žurnālists Džeimss Franklins (James Franklin), Bendžamina Franklina (Benjamin Franklin) vecākais brālis, tika apcietināts par atteikšanos atklāt savu informācijas avotu, norisinājās 1722. gadā, kad vēl pat nebija nostiprinātas tiesības uz vārda un preses brīvību. Taču arī vairākus simtus gadu vēlāk situācija nav īpaši mainījusies, jo, pirmkārt, žurnālisti turpina par savu profesionālu pienākumu uzskatīt nepieciešamību neatklāt informācijas avotus pat pēc tiesas pieprasījuma un, otrkārt, par šādu atteikumu joprojām tiek apcietināti pat Amerikas Savienotajās Valstīs (turpmāk - ASV), kur tradicionāli vārda brīvības aizsardzība tiek uzskatīta par vienu no visspēcīgākajām pasaulē. Tā, piemēram, ASV laikraksta The New York Times žurnāliste Džūdita Millere (Judith Miller) bija apcietinājumā 85 dienas par atteikšanos sniegt liecību tiesā un atklāt savu informācijas avotu. ${ }^{18} \check{S}_{\overline{1}}$ tiesvedība ir radījusi loti plašu un arī pretrunīgu rezonansi visā pasaulē un regulāri tiek pieminēta jautājumos par žurnālistu un viṇu avotu konfidencialitāti. Žurnāliste tomēr beigās atklāja sava informācijas avota identitāti, pirms tam pārliecinoties, ka avots piekrīt šādai rīcībai. ${ }^{19}$

Taču šis ir ne tikai profesionālās ètikas jautājums. Atsevišķās valstīs arī normatīvā līmenī ir nostiprināts žurnālistu pienākums neatklāt savus informācijas avotus. Šajā jautājumā īpaši tiek pieminēta Zviedrijas pieeja. Tiek uzskatīts, ka Zviedrijas regulējums par žurnālistu informācijas avotu aizsardzību ir viens no stingrākajiem, jo tam ir konstitucionāls spēks. Zviedrijas Preses brīvības likums, kas ir daḷa no Zviedrijas konstitūcijas, žurnālistiem paredz kriminālatbildību ar cietumsodu līdz pat vienam gadam, ja tiek pārkāpta avotu konfidencialitāte. Turklāt kriminālatbildība iestājas neatkarīgi no tā, vai avots tika atklāts aiz neuzmanības vai ar tīšu nolūku. ${ }^{20}$ Attiecīgi arī Zviedrijas žurnālisti avotu aizsardzību

${ }_{16}$ Brady R. 2004, p. 25.

17 Skat., piemēram, Belt Gordon T., Jailed \& subpoenaed journalists - a historical timeline. Pieejams: https:// www.freedomforuminstitute.org/wp-content/uploads/2016/10/Jailed-subpoenaed-timelinel.pdf [aplūkots 09.03.2021.].

18 Wallace S. The Journalist-Source Relationship in Context: A Comparative Review of US and English Law. Common Law World Review, 2008, Vol. 38, p. 270.

19 Belt Gordon T. Jailed \& subpoenaed journalists - a historical timeline. Pieejams: https://www.freedomforuminstitute.org/wp-content/uploads/2016/10/Jailed-subpoenaed-timeline1.pdf [aplūkots 09.03.2021.].

${ }^{20}$ Posetti J. Protecting Journalism Sources in the Digital Age. UNESCO, 2017, p. 113. Pieejams: https://www.wan-ifra.org/sites/default/files/field_article_file/UNESCO_Protecting_Sources.pdf [aplūkots 09.03.2021.]. 
kā savu pienākumu uztver l̦oti nopietni. ${ }^{21}$ Tie, kuri atbalsta pieeju, ka avotu aizsardzībai ir jābūt žurnālistu pienākumam, par kura pārkāpumu ir piemērojama kriminālatbildība, uzskata, ka šāda atbildība ir bijusi pamatā veiksmīgajam avotu aizsardzības regulējumam. Tas tiek uzskatīts kā pamats tam, ka avoti, kuri vēlas saglabāt anonimitāti, jūtas pārliecinoši, lai izpaustu informāciju. ${ }^{22}$ Jānorāda gan, ka šim pienākumam tomēr pastāv arī atsevišķi izṇēmumi ${ }^{23}$, taču tie attiecas uz situācijām, kad tiesībsargājošās iestādes var pieprasît žurnālistam atklāt viṇa informācijas avotu, nevis dod tiesības noteiktās situācijās žurnālistam pašam izlemt par labu sava informācijas avota atklāšanai.

No iepriekš minētā var secināt, ka gan žurnālistu profesionālās darbības organizācijām, gan arī likumdevējiem ir atšksirīga pieeja jautājumā par to, vai noteikt žurnālistu informācijas avotu aizsardzību kā absolūtu pienākumu. Pēc autores domām, nebūtu atbalstāma pieeja nacionālajos tiesību aktos noteikt žurnālistu absolūtu pienākumu neatklāt savus avotus, kā arī jebkāda veida atbildību par šāda pienākuma neievērošanu. Savukārt ētikas kodeksos būtu jāparedz iespēja piemērot izṇēmuma gadỉjumus no vispārīgā profesionālā pienākuma aizsargāt un attiecīgi neatklāt informācijas avotus. Šādi izṇēmuma gadījumi būtu nosakāmi nevis situācijās, kad tiesībsargājošās iestādes pieprasa atklāt informācijas avotu identitāti, bet gan situācijās, kad avota atklāšana ir sabiedrības interesēs un bez avota atklāšanas šādas intereses nav iespējams īstenot. Kaut arī par šo jautājumu ECT pagaidām nav devusi savu vērtējumu, ir būtiski atcerēties, ka avotu aizsardzība kā daḷa no tiesībām uz vārda brīvību nav noteikta ne žurnālista, ne arī avota interesēs, bet gan sabiedrības interesēs. ${ }^{24}$ Attiecīgi var pastāvēt situācijas, kad sabiedrības interesēs tomēr ir atklāt, piemēram, negodprātīga informācijas avota identitāti, tāpēc šāds izṇēmums no vispārējā pienākuma aizsargāt informācijas avotu būtu nepieciešams.

Šādu pieeju atbalsta arī starptautiskā vārda brīvības organizācija Article 19, kas uzskata, ka pienākuma uzlikšana žurnālistiem neatklāt savus avotus var potenciāli radīt nopietnas problēmas. ${ }^{25}$ Arī Amerikas valstu organizācijas "Ziņotājs vārda brīvības jautājumos" (Rapporteur for Freedom of Expression) ir norādijis, ka tiesības uz informācijas avotu aizsardzību nerada pienākumu sargāt informācijas avotu, izṇemot gadijumus, kad to paredz profesionālās uzvedības vai ètikas normas. ${ }^{26}$ Savukārt ASV Profesionālo žurnālistu biedrības Ētikas kodekss ${ }^{27}$ aicina žurnālistus izvērtēt informācijas avotu norādītos iemeslus, pirms tiem tiek apsolïta anonimitāte. Tiek rekomendēts anonimitāti piešķirt tiem avotiem, kuriem var

21 Posetti J. 2017, p. 113.

22 Turpat.

${ }^{23}$ Hendler C. A Swedish Shield, Unraised. How much protection can WikiLeaks offer? 02.09.2010. Pieejams: https://archives.cjr.org/campaign_desk/a_swedish_shield_unraised.php\#: :text=Unlike\%20 reporter's $\% 20$ shield\%20laws\%E2\%80\%94which,to\%20reveal\%20a\%20confidential\%20source [aplūkots 09.03.2021.].

${ }^{24}$ Freedom of Expression and Public Order. Training manual. UNESCO, 2015, p. 35. Pieejams: https:// unesdoc.unesco.org/ark:/48223/pf0000231305 [aplūkots 09.03.2021.].

25 Posetti J. 2017, p. 114.

26 "Privacy International" pētïjums "Silencing Sources: An International Survey of Protections and Threats to Journalists' Sources”, 27. lpp. Pieejams: https://papers.ssrn.com/sol3/papers.cfm?abstract_id=1706688 [aplūkots 09.03.2021.].

27 Society of Professional Journalists Code of Ethics. Pieejams: https://www.spj.org/ethicscode.asp [aplūkots 09.03.2021.]. 
draudēt briesmas, sods vai cits kaitējums un kuriem informāciju nav iespējams iegūt citā veidā kā vien no konkrētā informācijas avota.

Autores ieskatā, sabiedrības interešu izņēmuma noteikšana žurnālistu profesionālajam pienākumam aizsargāt savus informācijas avotus varētu kalpot arī kā preventīvs līdzeklis, lai atturētu negodprātīgus informācijas avotus, kuru mērḳis ir nevis sniegt informāciju sabiedrības interesēs, bet gan izmantot žurnālistu negodprātīgiem nolūkiem.

Protams, situācijās, kad avots, iespējams, ir rīkojies negodprātīgi, būtu izvērtējams, vai šādā gadījumā vispār ir pamats atsaukties uz informācijas avota aizsardzības pienākumu. ECT ir atzinusi, ka ne katra persona, kuru žurnālists izmanto informācijas iegūšanai, ir uzskatāma par “avotu” ECT tiesu prakses izpratnē, jo ir jānošķir "avoti to tradicionālā izpratnē”, kuri palīdz medijiem informēt sabiedrību par tai svarīgiem jautājumiem, no lietā Stichting Ostade Blade v. the Netherlands ${ }^{28}$ izskatāmā gadījuma, kad informatora mērḳis nebija sniegt tādu informāciju sabiedrībai, kuru tai ir tiesības zināt. Gluži pretēji, informators uzņēmās atbildību par noziegumiem, kurus pats bija veicis. Līdz ar to viņa mērķis, meklējot publicitāti ar laikraksta starpniecību, bija noṇemt anonimitāti noziegumam, par kuru viņš pats bija atbildīgs. Tādējādi ECT secināja, ka šādai personai nepienākas tāda pati "avota" aizsardzība kā, piemēram, lietā Goodwin v. the United Kingdom un citās. ${ }^{29}$

No minētā ECT sprieduma varētu secināt, ka informācijas avota aizsardzības nodrošināšanai ir būtisks personas, kura sniedz žurnālistam informāciju, rīcības mērķis un tiesiskums, taču šajā spriedumā ietvertās atziņas nebūtu interpretējamas paplašināti un atrauti no konkrētiem lietas apstākḷiem. Kā izriet no vairākām citām ECT lietām, žurnālistu informācijas avotu aizsardzība nav atkarīga no avotu rīcības tiesiskuma vai prettiesiskuma. ${ }^{30}$ Šādas atziṇas pamatā ir ECT pieeja, ka jebkurai avota izpaušanai var būt atvēsinošs iespaids uz potenciālo avotu gatavību nodrošināt žurnālistus ar informāciju neatkarīgi no informācijas veida, ko piedāvā avots. ${ }^{31}$ Tādējādi katra situācija būtu izvērtējama individuāli, rūpīgi izsverot iesaistītās intereses, taču fakts, ka avota sniegtā informācija ir, piemēram, izrādījusies nepatiesa, pats par sevi nebūtu pietiekams pamatojums atklāt informācijas avota identitāti.

\section{II}

Arī Latvijā žurnālisti ir pierādījuši, ka savu profesionālo pienākumu sargāt informācijas avotus stāda augstāk par pienākumu izpildìt tiesas lēmumu. Tā, piemēram, 2007. gadā "Neatkarīgās Rīta Avīzes” žurnālists Uldis Dreiblats tika notiesāts pēc Krimināllikuma 296. panta ar naudas sodu desmit minimālo mēnešalgu apmērā par to, ka nav izpildijis tiesas lēmumu atklāt Drošības policijas Izmeklēšanas nodaḷai savu informācijas avotu, kas sniedza ziņas - telefonu sarunu ierakstus,

${ }^{28}$ ECT 27.05.2014. lēmums lietā Stichting Ostade Blade v. the Netherlands (iesnieguma Nr. 8406/06).

29 Turpat, 65. $\$$.

${ }^{30}$ European Court of Human Rights factsheet "Protection of journalistic sources", October 2020. Pieejams: https://www.echr.coe.int/Documents/FS_Journalistic_sources_ENG.pdf [aplūkots 09.04.2021.].

${ }^{31}$ Council of Europe. Recommendation No. R (2000) 7 of the Committee of Ministers to Member States on the right of journalists not to disclose their sources of information. Committee of Ministers. $701^{\text {st }}$ meeting of the Ministers' Deputies. Article 5 of the Explanatory Memorandum, 8 March 2000. 
kuri, žurnālista ieskatā, liecināja par to, ka politiķi ir mēǵinājuši ietekmēt tiesībsargus, lai slēptu noziedzīgus nodarījumus. ${ }^{32}$

Latvijas Žurnālistu asociācijas Ētikas kodekss paredz, ka žurnālistam nav tiesību atklāt informācijas avotu bez tā piekrišanas. ${ }^{33}$ Savukārt Latvijas Žurnālistu savienības ètikas kodekss paredz izṇēmumu no šì pienākuma gadījumos, kad informācijas avota atklāšana tiek pieprasīta tiesā. ${ }^{34}$ Tātad pēc būtības šie izṇēmumi nepiel̦auj iespēju pašam žurnālistam noteiktā situācijā izlemt par labu informācijas avota atklāšanai.

Interesanti, ka starptautiskajos pētījumos, kas skar arī šo jautājumu, līdzās Zviedrijas regulējumam tiek izcelta arī Latvija kā viena no tām retajām valstīm, kurā žurnālistiem paredzēta administratīva atbildība par savu informācijas avotu atklāšanu. ${ }^{35}$

Likuma "Par presi un citiem masu informācijas līdzekḷiem" 22. panta pirmajā daḷā cita starpā ir noteikts, ka, ja persona, kura sniegusi informāciju, prasa, lai tās vārds netiktu norādìts masu informācijas lìdzeklī, šì prasība redakcijai ir saistoša. Turklāt par informācijas avota izpaušanu masu informācijas līdzeklī, ja masu informācijas līdzeklis to apṇēmies neizpaust, piemēro brīdinājumu vai naudas sodu fiziskajai un juridiskajai personai līdz vienam tūkstotim eiro. ${ }^{36}$ Tādējādi Latvijas regulējums paredz pienākumu neatklāt informācijas avotu, ja avots ir pieprasījis konfidencialitāti. Šì prasība gan neattiecas uz situācijām, kad informācijas avota atklāšanu ir uzdevusi tiesa, jo, saskaṇā ar likuma "Par presi un citiem masu informācijas līdzekḷiem” 22. panta otro daḷu, Lai aizsargātu personas vai sabiedrības būtiskas intereses, tikai tiesa, ievērojot samērīgumu, var uzdot norādīt informācijas avotu.

No minētā regulējuma secināms, ka pienākums neatklāt informācijas avotu un sods par šì pienākuma pārkāpumu ir piemērojams tikai tādos gadījumos, kad avots ir izvirzijis prasību neatklāt tā identitāti tieši masu informācijas līdzeklī. Lìdz ar to šì norma nebūtu piemērojama gadījumā, kad avota identitāte tiek atklāta tiesībsargājošām iestādēm vai jebkurai trešajai personai. Šādā veidā praktiskais lietojums minētajam regulējumam ir minimāls, jo attiecas uz informācijas avota izpaušanu tikai masu informācijas līdzeklī. Attiecīgi šobrīd spēkā esošais regulējums būtu pilnveidojams.

Izvērtējot nepieciešamību saglabāt tiesību aktos naudas sodu par informācijas avota atklāšanu, likumprojekta anotācijā ${ }^{37}$ tika norādīts, ka informācijas avota aizsardzība ir ne tikai žurnālista tiesības, bet arī pienākums. Atsaucoties uz ECT praksi, secināts, ka žurnālistiem jāspēj garantēt informācijas avotu konfidencialitāti un anonimitāti, jo tikai tā iespējams nodrošināt mediju pieeju konfidenciālai,

32 ECT 04.06.2013. lēmums lietā Dreiblats v. Latvia (iesnieguma Nr. 8283/07).

${ }^{33}$ Latvijas Žurnālistu asociācijas Ētikas kodeksa 3.1. punkts. Pieejams: http://www.latvijaszurnalisti.lv/ etikas-kodekss/ [aplūkots 09.03.2021.].

${ }^{34}$ Latvijas Žurnālistu savienības Ētikas kodeksa 4. punkts. Pieejams: http://www.zurnalistusavieniba.lv/ index.php? $\mathrm{p}=3519 \&$ lang=923\&pp=3768 [aplūkots 09.03.2021.].

35 "Privacy International" pētijums "Silencing Sources: An International Survey of Protections and Threats to Journalists' Sources”, 27., 28. lpp. Pieejams: https://papers.ssrn.com/sol3/papers.cfm?abstract_id=1706688 [aplūkots 09.03.2021.].

36 Par presi un citiem masu informācijas līdzekḷiem: LV likums. Pieṇemts 20.12.1990. [18.11.2020. red.], 31. pants.

37 Likumprojekta "Grozijumi likumā "Par presi un citiem masu informācijas līdzekḷiem”" sākotnējās ietekmes novērtējuma ziṇojums (anotācija). Pieejams: https://titania.saeima.lv/LIVS13/saeimalivs13.nsf/0/BB 5E2E70274F2A06C225847F004525E5?OpenDocument [aplūkots 09.03.2021.]. 
bet sabiedrībai būtiskai informācijai. Tāpat arī norādīts, ka šì pienākuma neievērošanas sekas var ietekmēt sabiedrības pārstāvju vēlmi un iespējas sadarboties ar masu informācijas līdzekḷiem informācijas sniegšanā.

Kā izriet no likumprojekta anotācijas, žurnālistu profesionālās organizācijas neiebilda pret ierosinātajiem grozījumiem, kas turklāt paredzēja naudas sodu palielināt no iepriekš noteiktajiem 350 eiro līdz 1000 eiro. Šāda nostāja visdrīzāk liecina par to, ka, žurnālistu un mediju ieskatā, šāda tiesību norma nav aktuāla, jo žurnālisti nepārkāpj savu pienākumu sargāt informācijas avotu konfidencialitāti. Uz to norāda arī likumprojekta anotācijā ietvertā statistika, ka kopš 2010. gada nav piemēroti sodi par informācijas avota noslēpuma pārkāpumu. Turklāt 2010. gadā Latvijas mediju darbinieki lūdza veikt grozijumus likumā "Par presi un citiem masu informācijas līdzekḷiem”, tieši paredzot kā vienu no žurnālistu pienākumiem glabāt informācijas avota noslēpumu, ja persona, kura sniegusi informāciju, prasa, lai tās vārds netiktu izpausts. ${ }^{38}$ Neskatoties uz to, ka šādi grozījumi netika pieņemti, tie norāda uz žurnālistu un mediju pārliecību, ka informācijas avotu aizsardzība ir viņu absolūts pienākums, nevis tiesības.

Kaut arī šāds normatīvs pienākums var sniegt priekšrocības negodprātīgiem informācijas avotiem, jāṇem vērā, ka žurnālistiem ir arī pienākums pārbaudīt saņemto informāciju, nepaḷaujoties tikai uz informācijas avota sniegtajām ziṇām. Pirms žurnālists apsola avotam konfidencialitāti, ir jāapsver vairāki faktori. Primāri būtu jānoskaidro, vai piedāvātā informācija ir sabiedrības interesēs. Tāpat arī ir jāapsver, vai nepastāv iespēja, ka avots manipulē ar žurnālistu. L,oti liela nozīme ir avota uzticamībai, kā arī tam, vai šo informāciju nav iespējams iegūt citā veidā. ${ }^{39}$

\section{Kopsavilkums}

1. Lielākā daḷa žurnālistu gadiem ilgi savu informācijas avotu aizsardzību ir uzskatījuši par absolūtu profesionālo pienākumu un ir stādījuši to augstāk pat par tiesas un likuma varu, izvēloties drīzāk doties apcietinājumā nekā atklāt savus informācijas avotus.

2. Kaut arī lielā daḷā valstu un starptautisko žurnālistu organizāciju profesionālās darbības un ètikas kodeksi paredz žurnālistu pienākumu sargāt savus informācijas avotus, šis jautājums nav viennozīmīgs un būtu izlemjams katrā konkrētā situācijā individuāli. Primāri būtu jāuzskata, ka žurnālistam ir pienākums sargāt sava informācijas avota identitāti, taču piel̦aujot arī izṇēmumus no šì pienākuma.

3. Tā kā avotu aizsardzība ir noteikta sabiedrības interesēs, var būt situācijas, kad sabiedrības interesēs tomēr ir atklāt, piemēram, negodprātīga žurnālista informācijas avota identitāti, tādējādi nacionālajos tiesību aktos nebūtu pamata noteikt žurnālistu absolūtu pienākumu neatklāt savus avotus, kā arī jebkāda veida atbildību par šāda pienākuma neievērošanu. Savukārt ētikas kodeksos būtu jāparedz iespēja piemērot izṇēmuma gadījumus no vispārīgā profesionālā pienākuma aizsargāt informācijas avotus.

\footnotetext{
38 Atklātā Latvijas mediju darbinieku vēstule, 14.05.2010. Pieejams: https://www.lsm.lv/raksts/zinas/latvija/atklata-latvijas-mediju-darbinieku-vestule.a43194/ [aplūkots 09.03.2021.].; likumprojekts “Grozijums likumā “Par presi un citiem masu informācijas līdzekliem”", 19.05.2010. Pieejams: https://titania.saeima.lv/LIVS/ SaeimaLIVS.nsf/0/749DAE20181A0EBDC22577280049C2D0?OpenDocument [aplūkots 09.03.2021.].

39 Posetti J. 2017, p. 286.
} 
4. No Latvijas regulējuma izriet, ka pienākums neatklāt informācijas avotu un sods par šĩ pienākuma pārkāpumu ir piemērojams tikai tādos gadījumos, kad avots ir izvirzījis prasību neatklāt tā identitāti tieši masu informācijas līdzeklī. Līdz ar to šì norma nebūtu piemērojama gadījumā, kad avota identitāte tiek atklāta tiesībsargājošām iestādēm vai jebkurai trešajai personai. Šādā veidā praktiskais lietojums minētajam regulējumam ir minimāls, jo attiecas uz informācijas avota izpaušanu tikai masu informācijas līdzeklī. Attiecīgi šobrīd spēkā esošais regulējums būtu pilnveidojams. 